\title{
FROM ELITE TO MASS TO UNIVERSAL HIGHER EDUCATION: FROM DISTANCE TO OPEN EDUCATION
}

\author{
(DE LA EDUCACIÓN SUPERIOR DE ELITE A LA MASIVA UNIVERSAL: DE EDUCACIÓN A \\ DISTANCIA A LA ABIERTA)
}

\author{
Larry Cooperman \\ University of California (USA)
}

\begin{abstract}
In 1970, Martin Trow, a professor at the University of California, Berkeley, identified a transition "underway in every advanced society - from elite to mass higher education and subsequently to universal access." This paper adapts this framework of the historical and structural development of higher education as a phased process in which absolute and relative growth of university enrollment transforms the institutions of higher education and alters its functions. The transition to universal access may support economic development, social mobility and greater income equality, in turn buttressing even the institution of democracy. Arriving at those optimal social outcomes isn't automatic, however, because of a variety of remaining issues: how universality of higher education translates to economic growth and social equality. The problem of the "next 1\%," shorthand for the continued entrance of new social layers into higher education, presents novel challenges that "access" alone may not solve.
\end{abstract}

Keywords: open course ware, MOOCs, open educational resources, higher education, social mobility, access.

\section{RESUMEN}

En 1970, Martin Trow, profesor de la Universidad de California, Berkeley, identificó una transición "en camino en cada sociedad avanzada - de la elite a la educación superior de masas y, posteriormente, a un acceso universal". Este artículo adapta el marco del desarrollo histórico y estructural de la educación superior como un proceso gradual en el que el crecimiento absoluto y relativo de la matrícula universitaria transforma las instituciones de educación superior y altera sus funciones. La transición hacia el acceso universal puede apoyar el desarrollo económico, la movilidad social y una mayor igualdad de ingresos, a su vez apuntalar incluso la institución de la democracia. Llegar a esos resultados sociales óptimos no es automático, sin embargo, debido a una serie de cuestiones pendientes: ¿cómo se traduce la universalidad de la educación superior al crecimiento económico y la igualdad social. El 
problema de la "próxima al 1\%", la abreviatura de la entrada continua de nuevas capas sociales a la educación superior, presenta nuevos desafíos que el "acceso" por sí solo podría no resolver.

Palabras clave: cursos abiertos, MOOCs, recursos educativos abiertos, educación superior, movilidad, acceso.

The postwar era of mass education was the result of government policy, first in the United States, then in Europe, and then through even more forceful central governmental intervention, in Asia. This transformation of the university's function itself affected not only public universities, but also the private, nonprofit universities. Together, the first public universities and the often older private, sometimes religious ancestors were systems that educated the elite through sorting mechanisms that utilized both meritocratic and hereditary practices. Today, the Internet provides immediate and universal access to knowledge and information that used to be reserved behind closed doors for academic communities. However, that immediacy and universality of access has not, does not, and will not provide for the vast expansion of graduation rates from postsecondary institutions that will be required in the future to fulfill three core missions of higher education: an educated citizenry, solution of core social problems, such as public health and sustainability, and preparation of an advanced global workforce. The reason is that learning relies on prior knowledge and gaps in that prior knowledge that stem from inadequate primary and secondary preparation are not easily overcome - and certainly not without a conscious curricular design, technology-assisted mechanisms and new public policies to promote rapid pathways over remediation.

Martin Trow is the scholar most identified with the elite-mass-universal (access) transitions. (Unterhalter, 2006) In his schema, "universal" referenced the wide availability of community colleges that practiced open enrollment and were physically within reach of the vast majority of the population. Hence access, though not necessarily enrollment, had become universal. The growth of the Internet has also meant the establishment of virtual universities that enroll hundreds of thousands of students and that are often among the largest in the countries where they are present. Currently, particularly in countries where the graduation rate is suboptimal, free, public courses could play a role in expanding both access and, if not enrollment, then at least the opportunity to earn transferrable university credit toward credentials recognized in the workplace.

If technology-mediated learning pathways have the potential to expand access, then the quality and the capacity of learning technologies will play an outsized role in both residential, distance and open education. Both traditional universities and 
MOOCs are learning to use analytics to predict student success and failure and to develop appropriate interventions. However, technologies that support entrants from new social layers accessing higher education for the first time are still in their infancy. In particular, adaptive technologies that seek to understand an individual student's conceptual gaps, or even his capacity to write well, must increasingly play a role if the goal of this expanded access is to promote social mobility and income equality.

Universal access is also related to free or low-cost education. In fact, the massification of higher education in the United States occurred through federal programs that offered tuition designed first for demobilized soldiers and later through other forms of federal support for higher education. The Master Plan for Higher Education stipulated that fees could only be charged for "costs not related to instruction". The "mass to elite to universal" transition envisioned by Trow relied on something besides physical access to a campus: low cost or free tuition. Only when Ronald Reagan, later president of the United States, became governor of California, did the University begin to charge for educational costs and, even then, it was initially proposed as a fee for capital outlays. In the few countries that have seen reversals of the general international upward trend in percentages of the population with a college degree, significant tuition increases seem to have played an important role. So the issue of "free" in both public higher education, but also open education merits its own discussion.

Finally, for universal access to become a global policy in the way that it is for primary education and a realizable goal for secondary education, it has to have a justification that goes beyond the social benefits of an educated citizenry. For example, higher education can be used to push the potential economic growth curve outwards. Yet there are examples of governments that have disguised unemployment and attempted to quiet social unrest by guaranteeing graduates spots in the government bureaucracy. Between these two scenarios - a surplus of college graduates and a socially beneficial increase in economic development - is a world of difference. Under what conditions does the increase in access to higher education result in positive social outcomes, both for the individual and for society?

In the four sections of this paper, the core questions that govern the pace of the phase of universal access to higher education as a global phenomenon are examined. In the first section, "Expansion of Higher Education and the Promise of Open Education", a brief overview of the unevenness of global expansion of higher education is provided, including the tension between the rising burden of education on families and students and the resulting demand, sometimes for free education, 
sometimes for lower-cost education. From this picture emerges the use of open education in all of its varieties -from Open Course Ware to MOOCs - to reduce costs while supporting baseline quality, precisely the mechanism that made the adoption of distance education so urgent.

In the second section, the "Next 1\% Problem", the question is raised of the coordination between primary, secondary and tertiary education. The entrance of new social layers into higher education, typified by the phrase "the first one in my family to attend university," brings with it new issues, including the average level of primary and secondary preparation. Since university education and postsecondary education typically result in lower unemployment rates and higher lifetime incomes, it is natural that parents would sacrifice to permit even one of their children to attend. However, the type of education that is required under these circumstances combines remediation for gaps along with the normal course of studies. If the course of study is lengthened in time, then the financial burden is increased and the rate of noncompletion rises. How technology-mediated environments in distance and open education address this issue becomes a key question. Failure to do so implies that the transition to universal access will at the best be an extremely lengthy affair.

In the third section, the history of free, public higher education is compared to the use of open education as a mechanism for the phase of universal access. Open education has, to date, been disproportionately accessed by those who already hold university degrees. This is true of Open Course Ware, which continues its ascent, in absolute number, of total accesses. But it is also true of the rise of MOOCs. New initiatives, including the plan by the U.S. State Department to use the Coursera platform to launch a high-quality, multilingual, universal-access global project are too new to provide any lessons. However, if the project aims at the current audience of the MOOCs, it may miss the opportunity to prepare educationally appropriate treatments that raise the average level of education in cost-effective ways.

In the fourth section, "The Problem of Social Outcomes”, universal access to higher education is viewed from the prism of the broader economy. If the driver of ever-increasing percentages of college graduates is the tie-in between degreeholding and lifetime incomes and higher employment rates, this is not an automatic mechanism. Several countries, entering into economic crises, have actually seen an inversion of this relationship and, at least temporarily, they experienced a negative correlation between education and employment. Furthermore, universal access may play out differently between high-income countries and low-income countries as the relative usefulness of producing an extra civil engineer may vary under austerity regimes in Europe and, to a lesser degree, the United States, while the potential 
productivity gain will be higher in Latin America, which continues to import European professionals for large infrastructure projects, Cuban doctors (Brazil) for extension of medical services.

In short, the goal of this paper is to examine the notion of "higher education for all" as it has gained traction as a slogan. To do this, Trow's understanding of a phased transition in higher education is employed and coupled to a look at the role of open education as a motor of that transition. Its promise of "education for all" was inherent in the announcement of OpenCourseWare at MIT in 2000, furthered by the adoption of UNESCO of the category of "open educational resources", and joined by the instructional features and data analysis of the MOOCs in 2011. However, the mechanisms for the achievement of this goal must necessarily vary from region to region, given the starting point of elite-level percentages for sub-Saharan Africa versus mass levels in Western Europe and the United States and quasi-universal levels in South Korea.

\section{EXPANSION OF HIGHER EDUCATION AND THE PROMISE OF OPEN EDUCATION}

In the transition from elite to mass systems of higher education, Trow made a number of points about both the quantitative and qualitative aspects of the transformation of universities. He noted that both the rate of growth and the absolute size matter (Trow, 1973). If, today, Brazil doubled its gross enrollment ratio in ten years, it means that both the percentage of students in an age group increased as well as creating pressure on the system to create new institutions of mass higher education. This latter process was reflected in both the vast expansion of distance education, the increase of the private for-profit sector, and the development, more recently, of a national open university, the Universidade Aberta do Brasil, that partners with federal universities in Brazil to disseminate through distance education its programs throughout the country. A quick look at the growth rate of tertiary graduation attainment shows the following for the reported years of 2007-2011 among 25-34 year olds: (2007)12\%, (2009)13\%, (2009)13\%, (2010) not reported, and (2011)15\%. But pushing these numbers upwards is the tremendous growth of secondary graduation rates, including those who didn't complete tertiary education: an average growth rate of nearly $39 \%$ for those five years.

Between 2002 and 2009, global higher education enrollment rose 6\% per year, higher than any comparable period. Access to higher education is very precious as it confers on degree holders a significant earnings advantage throughout their lifetime. The issues of cost and access become intertwined as dual barriers to equal 
opportunity in an era in which higher education is increasingly seen as a universal right, the logical consequence of its massification. What is clear is that there is an inexorable increase in enrollment driven by the perception and the reality that university education is the gateway to a brighter future. A 2009 OECD report shows an average annual increase of $4.5 \%$ in university enrollments. And it cites both the prod that comes from growing employment insecurity for the lesser qualified in the labor markets as well as the incentive of higher net lifetime pay for those with university degrees.

Distance education served in many countries as the main vehicle for the expansion of higher education. Internationally, the adoption of increased costsharing at public higher universities has sparked a broad public debate over the cost of higher education and the level of indebtedness it causes for students and their families. The policy issue that is sometimes confused with the economic issue of the budgetary contribution of governments to higher education is increasingly one of democratic access to higher education institutions, the gatekeepers to national and individual prosperity.

On this stage, open education occupies a precarious perch. It appears to be the vehicle by which demands for lower-cost, higher quality university education can be achieved. But it can also become, as distance learning has frequently been, the vehicle for lower-quality higher education that can be provided efficiently and economically to the ever-larger percentages of secondary students who enter the tertiary sector.

The barriers to the penetration of open education as a vehicle for low-cost, high quality education have been variously described as technical, legal or even educational. This paper argues that these barriers are being or will be solved. Whether open education will become a successor to distance education in terms of providing higher education to ever larger numbers or whether its real promise is in achieving increased equality of opportunity through democratization of access.

While much of the conversation recently focuses on MOOCs, it ignores the development of massive universities with hundreds of thousands of matriculated students. In India, one public university has reached a scale that eclipses the course completion rates of the largest MOOCs combined: the Indira Gandhi National Open University (IGNOU). With 3 million enrollments in 3000 courses, it has attained a scale that in previous decades would have been unimaginable. Similarly, large openenrollment, distance education universities have developed in every region, from the Open University of UK to the former China Television and Radio University (now Open University of China) to UNISA in South Africa. Not surprisingly, the 
open universities have become prominent in their offerings of open education, from OERs to Open Course Ware to MOOCs. The adoption by IGNOU of an OER policy, supported by the Indian government, was designed to "radically increase the widespread availability of high-quality educational resources". (Kanjilal) The significance of the world's largest university producing what could quickly become the largest OER repository in the world cannot be understated. Furthermore, this is an indication that, for the developing world, there is no transition between distance and open education, only a combination of mechanisms to expand access to higher education. The proposals of India's National Knowledge Commission to create transferable credits and a national testing service offers a glimpse of the potential for open education to play a transformative role in the transition to universal access.

Open education, uses the technologies of distance learning and marries them to openly licensed content, simultaneously seeming to promise increased access to higher education and lower costs. Open education, however, is in the throes of change itself. While it was defined by its licensing schemes (from public domain to Creative Commons), it began life as course materials associated with a course. The introduction of OERs, in turn, disassociated these materials from even the organizing principle of a course. The reason for this was to support the objective of reusability. However, the introduction of MOOCs laid bare two core issues in these earlier iterations: (1) having a full instructional path matters to an audience of learners and (2) the goal of reusability may be important to producers of content, but not to learners. Nevertheless, the failure of MOOCs, such as Udacity and Coursera, to adopt anything more than the most restrictive licensing, Creative Commons Attribution, Noncommercial, No Derivatives (CC-BY-NC-ND), means that repurposing is impossible and the reuse case is diminished because the instructional narrative and design are fixed. The other prominent MOOC provider, EdX, has no common licensing standard for its courses, some of which are derived from MIT Open Course Ware. Others are public and free, but fully copyrighted.

Because the MOOCs have full instructional paths, they also can apply learner analytics as well as other data features, such as A/B testing. They follow the earlier work done at Carnegie-Mellon by the Open Learning Initiative, in which central data repositories captured user behavior, question responses were tested for validity as well as for learning, and course formats were subjected to testing, including options for accelerated learning (5-week versus 10-week formats).

Commercial providers as well as open-source software developers are also jumping into the breach to offer learning technologies that support scale through automated student assessment and address gaps in prior learning through adaptive 
learning technologies. In 2012, the Hewlett Foundation offered $\$ 100,000$ to the top three research teams that could develop automated essay-grading software. The goal of this technology was to permit the assignment of more writing by students through a mechanism to allow more rapid review based on a careful rubric created for each essay.

As education becomes increasingly digital, Web-mediated education increasingly relies on technologies to support instruction, whether at scale or not. The "next 1\% problem" requires advanced tools to solve some of the stickiest problems in higher education, such as the shortfall in university preparation.

Sources (OERs) and the slightly less finely grained OpenCourseWares (OCWs) into pedagogically sound, content-complete curricular paths. The second is to understand social, economic and policy barriers to the goal of universal access to higher education.

The flip side of the failure to find an egalitarian mechanism for the goals of increased access and lower costs can be seen in the student demonstrations in South Korea, Chile, Colombia and even the United States. As universities falter in the face of public funding cuts, students find themselves on the receiving end of costsharing strategies and the search for private revenues for has led universities into an increasingly fierce competition with each other.

Access to higher education is very precious as it confers on degree holders a significant earnings advantage throughout their lifetime. The issues of cost and access become intertwined as dual barriers to equal opportunity in an era in which higher education is increasingly seen as a universal right, the logical consequence of its massification. What is clear is that there is an inexorable increase in enrollment driven by the perception and the reality that university education is the gateway to a brighter future. A 2009 OECD report shows an average annual increase of 4.5\% in university enrollments. And it cites both the prod that comes from growing employment insecurity for the lesser qualified in the labor markets as well as the incentive of higher net lifetime pay for those with university degrees.

Internationally, the adoption of increased cost-sharing at public higher universities has sparked a broad public debate over the cost of higher education and the level of indebtedness it causes for students and their families. The policy issue that is sometimes confused with the economic issue of the budgetary contribution of governments to higher education is increasingly one of democratic access to higher education institutions, the gatekeepers to national and individual prosperity. 
On this stage, open education occupies a precarious perch. It appears to be the vehicle by which demands for lower-cost, higher quality university education can be achieved. But it can also become, as distance learning has frequently been, the vehicle for lower-quality higher education that can be provided efficiently and economically to the ever-larger percentages of secondary students who enter the tertiary sector.

The barriers to the penetration of open education as a vehicle for low-cost, high quality education have been variously described as technical, legal or even educational. This paper argues that these barriers are being or will be solved. It is whether open education will become a successor to distance education in terms of providing higher education to ever larger numbers or whether its real promise is in achieving increased equality of opportunity through democratization of access.

Open education uses the technologies of distance learning and marries them to openly licensed content, simultaneously seeming to promise increased access to higher education and lower costs.

Increasingly, there is a heavy price to be paid for failure to find an egalitarian mechanism for the goals of increased access and lower costs. This can be seen in the student demonstrations in South Korea, Chile, Colombia, Quebec and California. As universities falter in the face of public funding cuts, students find themselves on the receiving end of cost-sharing strategies and the search for private revenues for has led universities into an increasingly fierce competition with each other.

\section{THE “NEXT ONE PERCENT" PROBLEM}

The "next one percent" refers to the incremental costs and benefits of raising college entrance rates, the tertiary gross enrollment ratio, and graduation rates in a given country by an incremental amount. While it may seem like the deck is stacked in favor of benefits, there are also a number of downsides. Witness the issues arising in the United States - a mature, high income country - from the increase in student debt, the high rate of non-graduation within six years, and even the issue of the employment opportunities for recent college graduates.

In terms of student debt, now greater than $\$ 1$ trillion, Stiglitz has noted the tendency of excessive burdens to depress economic growth. Graduates and those who failed to graduate alone are left with a kind of debt that cannot be forgiven even in bankruptcy and consequently are forced to forestall purchasing decisions, such as homes and autos. In the case of parents who have gone into debt to finance their children's college education, the result can be an insecure retirement (Stiglitz, 2012). 
These issues have even inspired a new concern over the value of higher education. However, the income gap between college graduates and others is actually expanding. Partially, this phenomenon is explained not by a general rise in salaries for college graduates, but for the tendency of employers to hire a college graduate first, even when the work requires only a high school degree or less. The Center for College Affordability and Productivity released a report in January 2013 that demonstrated the mismatch of skills with jobs in two ways: (1) $37 \%$ of college graduates were working at jobs that required high school or less and another $11 \%$ at jobs requiring less than a bachelor's degree; and (2) that there were 41.7 million employed college graduates, but only 28.6 million jobs requiring college degrees (Vedder, Denhart and Robe, 2013). In other words, a surplus of college graduates removes available sources of employment from those with high school education or less and thereby depresses wages through increased unemployment and greater competition among workers with less than a college degree.

At the same time, the wage gap results in increased pressure for university attendance among not only 18-24 year-olds, but also among young adults who are struggling in the workforce. The lower unemployment rate, coupled with higher lifetime incomes, is, in fact, the motor force of the longterm trend towards universality of higher education. Figure 1 shows the growth patterns of two significant Latin American countries and compares them to the High-Income OECD nations:

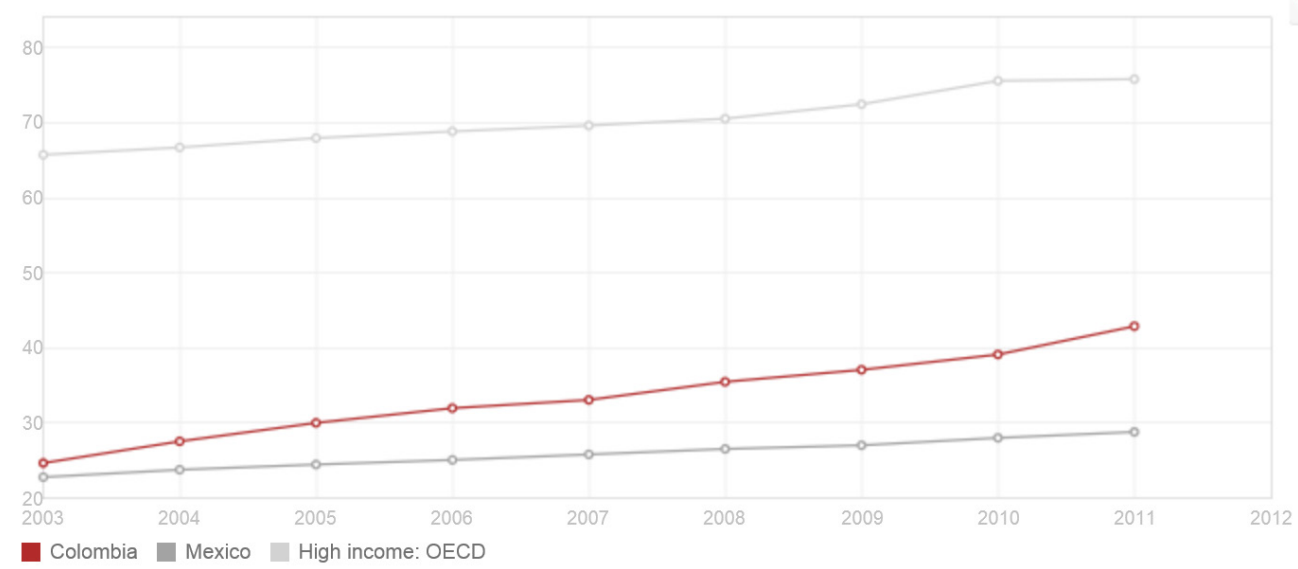

Figure 1. Tertiary School Enrollment (\% gross). Source: World Bank Indicators

Tertiary gross enrollment ratios measure the number of enrolled students divided by the population of age 18-24. Because it counts both enrolled 17-year-olds and 30 -year-olds in the numerator, but not the denominator, it produces a somewhat 
rosy view of the actual percentage of the population moving through the tertiary pipeline. But it does capture the rate of growth and we can see some countries, like Brazil and Colombia, have achieved dramatic increases in the number of students enrolled in postsecondary studies.

Another factor is the policy of governments across the globe to increase the percentage of the population holding college degrees. This policy inevitably starts with targets for secondary completion. In this 2005 World Bank report analyzing Turkey's higher education strategic options, it notes: "Low secondary school enrollment and attainment for Turkey-half the Lisbon target-present a serious constraint on access to higher education. Enrollment and completion of secondary education, which have increased in the past ten years, are still low by international standards. In 2005, 40 percent of 20 to 24 year olds had a secondary degree, one half of the rate for the EU15 and well below the Lisbon target of 85 percent" (Human Development Sector Unit, World Bank).

Do developing countries with lower tertiary enrollment rates face the same issues with respect to the transition to universal access? Figure 2 shows the region with the lowest tertiary gross enrollment ratio.

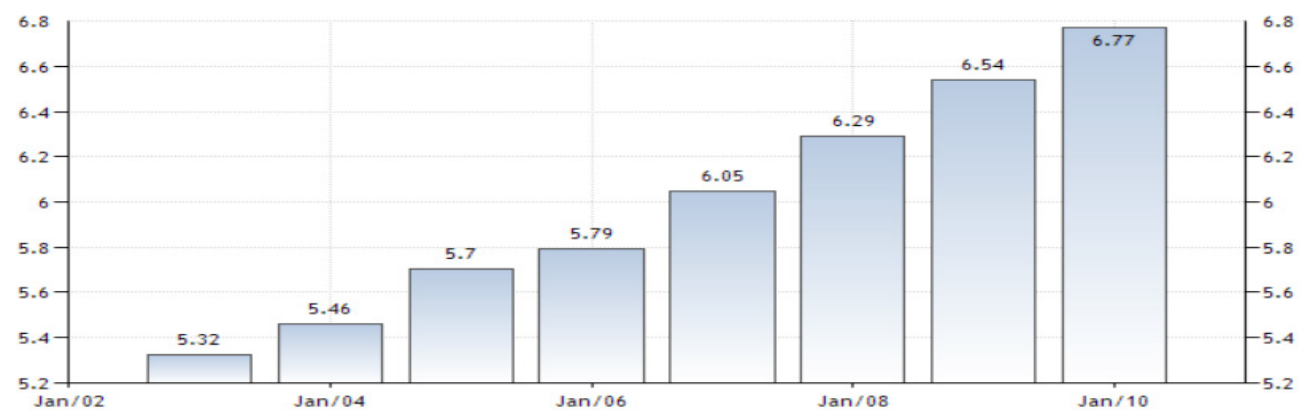

Figure 2. Tertiary gross enrollment ratio. Source: 2012 World Bank report, taken from http://www.tradingeconomics.com/sub-saharan-africa/school-enrollment-tertiary-percent-grosswb-data.html

To answer this question, it is important to consider the public benefits of higher education enrollment growth. In particular, do increased "years of education" and enrollment growth foster greater potential economic growth. Bloom, Canning and Chan, in their 2005 paper for the World Bank, provided the justification for changing the relative spending priorities toward increased support for tertiary enrollment: "Our analysis suggests that increasing tertiary education may be important in promoting faster technological catch-up and improving a country's ability to 
maximize its economic output. Our results show that Sub-Saharan Africa's current production level is about 23 per cent below its production possibility frontier. Our analysis indicates that, given this shortfall, increasing the stock of tertiary education by one year would shift out Africa's production possibility frontier and increase the rate of convergence to that frontier, resulting in a 0.63 percentage point boost to income growth in the first year and an income gain of roughly 3 percent after five years. It should be noted that this estimate is less than earlier estimates by Barro and Sala-i-Martin and by Jenkins. It should also be noted that the boost in the rate of convergence that follows from the additional higher education would diminish as Africa reached the theoretical ceiling" (Bloom, Canning and Chan, 2005). Bloom, Canning, and Chan show a larger effect on the production possibility frontier from the higher education effect in Africa than elsewhere. In essence, the graduation of a civil engineer in Africa may have a greater relative public benefit than it would in Europe or the United States.

\section{OPEN EDUCATION AND FREE EDUCATION}

Trow argues that the Europeans have sought to adopt the core features of the U.S. higher education because it is more suited to modern economies (Trow, 2006). However, the Europeans have maintained, despite sharp rises in tuition in the UK, significantly lower tuition costs, including at the private, nonprofit sector. But the United States is also remarkable for its use of federal sources of revenues to fuel the development of the higher education sector. In 1862, the Morrill Act, provided each state with the right to an amount of federal lands to sell or use, varying by the number of representatives. These land-grant colleges were to serve the public good, in particular through the establishment of colleges of agricultural and mechanics, while their forebears continued to educate society's elite. Only two of these landgrant colleges are private institutions, but this small list includes the Massachussetts Institute of Technology. Later the Morrill Act was expanded to include the secessionist South, but on condition of not permitting prohibition by race. The Historically Black Colleges were formed by this land grant mechanism.

Federal support for higher education in the United States and in Europe took on the task of turning demobilized soldiers into productive citizens. The rapid demobilization and the increase in university enrollments propelled the United States forward in the postwar era. 51\% of World War II veterans used their benefits for higher education expenses. "In the peak year of 1947, veterans accounted for 49 percent of college enrollment. Out of a veteran population of $15,440,000$, some 7.8 million were trained, including 2,230,000 in college, 3,480,000 in other schools, 
1,400,000 in on-job training, and 690,000 in farm training. Total cost of the World War II education program was $\$ 14.5$ billion” (GI Bill turns 62 today).

If the G.I. Bill launched the United States into the phase of systems of mass higher education, then the extension of higher education within a short drive of most population centers represented a transition to a modern, skilled workforce.

One of the controversies in higher education financing is whether tuition-free public universities, in effect, provide a subsidy to the more privileged social layers who disproportionately gain admission. Embedded in this controversy is the issue of whether universities, even those that are part of mass systems, effectively reproduce social inequality (Asplund, Ben Adbelkarim and Skalli, 2008).

The mere fact of free of low-cost tuition, particularly when the result of government financing, often requires a limit on enrollment capacity. In fact, South Korea, with its high tertiary gross enrollment ratio, places the highest burden on the student and his family to pay for higher education. An approach based on the costreduction features of distance education does not always provide equivalent quality, although these outcomes are at least partially the result of the targeted student population. Nor does distance education always deliver the cost-reduction benefits to students in the form of reduced-cost tuition.

The opportunity exists for a combined open-distance scaled approach which delivers free content together with technology-enhanced mechanisms for managing scale. The question, however, is one of policy. Will governments take advantage of these cost-reduction features to further reduce support public higher education? Or will they use it to usher in an era in which the selective use of scale supports ever higher graduation rates while maintaining the level of academic staffing? Or will it be the pretext for a "disruption," in which the usefulness of university credentials is lessened by the reduction in the number of positions that require a university degree? In the next section, this issue of social outcomes is examined further.

\section{THE PROBLEM OF SOCIAL OUTCOMES}

In a hypothetical future, all people of university-going age would enroll in undergraduate and then graduate programs, finishing with doctorates in a wide variety of areas. The question is whether this is a paradox in which years of education, far from being socially beneficial, end up destroying the social fabric by creating a set of unattainable expectations on the part of all the newly minted PhDs. MOOCs, by combining free, public content, with scaled instructional capabilities bring this 
paradox closer to the present. If we are entering into a phase of higher education in which all of the content and, increasingly, instructional paths are presented freely, would we need the current amount of university professors and lecturers?

The venture capital that now flows into startups that promise disruption of higher education may be merely bets. Will the university systems follow the newspaper industry down the path of starkly lowered employment or will the university in the phase of universal access chart a new course?

The network effects of the Internet are well-known. Social media, in particular, has benefited enormously from the adhesion of millions, both from the standpoint of the financial value of networks like Facebook as well as their utility to the user base. The size of the network itself and first-mover advantage dictate that only the largest new entrants, like Google, can compete in the space.

It has already been widely commented the disruption of publishing by the intertwined rise of free content and social networks. Huffington Post Live, for example, is a new streaming news and commentary channel designed as a web-based alternative to standard cable news shows (Pompeo, 2012). However, Huffington Post itself is an aggregator of traditional news outlets combined with a large (and largely unpaid) group of bloggers, many well-recognized, typically left-of-center political personalities and academics. In recognition of the value of this business model, AOL purchased Huffington Post for \$315 million in February 2011 (Peters and Kopytoff, 2012).

But the final test of this analogy will be the inverse relationship between the new aggregator and the old industry. That is, while blogging, in general, and Huffington Post, specifically, has risen in value while the newspaper industry has seen a wave of consolidations, bankruptcies, and downsizing. Figure 3 shows the accelerating decline of newspaper employment since 1997: 


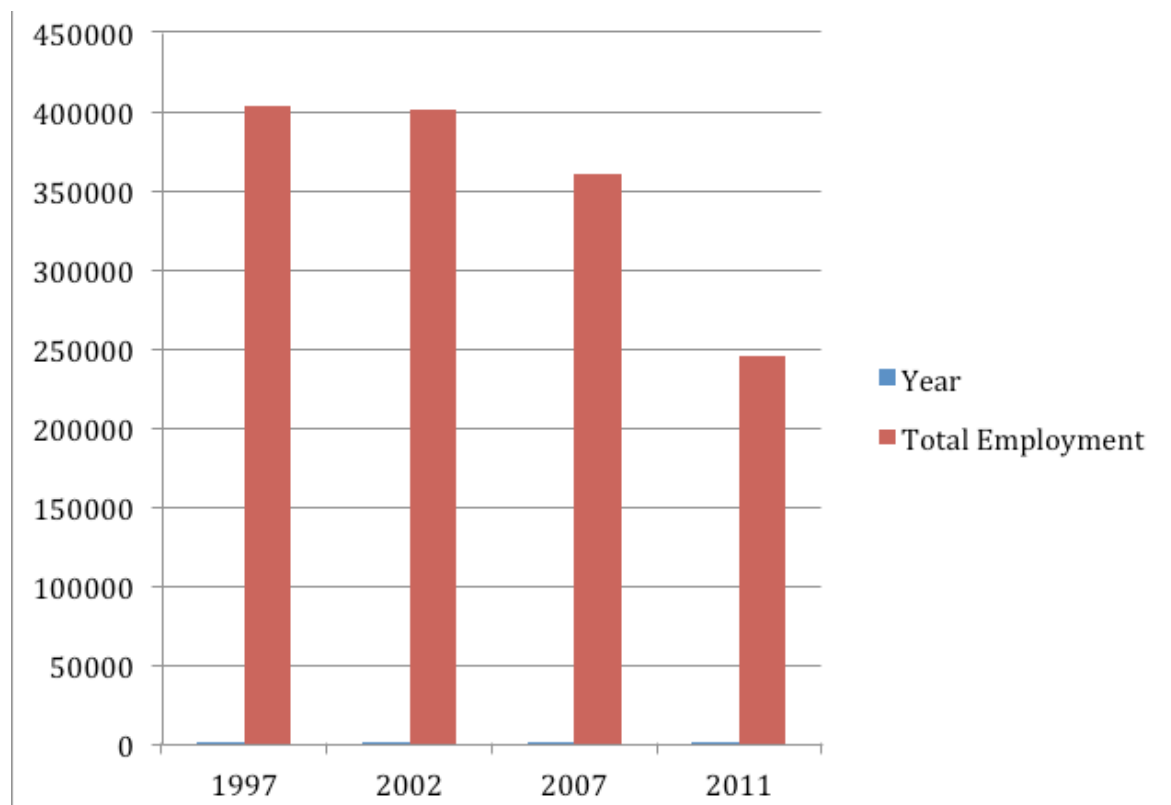

Figure 3. Total employment in the newspaper publishing industry 1997-2011. Source: Bureau of Labor Statistics, Newspaper Publishing Industry (NAICS code 511110)

Of course, this picture has not yet been replicated at all within higher education. Table 1 paints a picture of slow growth of both full-time and part-time positions in higher education from 2003-2009.

\begin{tabular}{|l|l|l|l|l|l|l|l|l|}
\hline & \multicolumn{2}{|c|}{ Fall 2003} & \multicolumn{2}{c|}{ Fall 2005 } & \multicolumn{2}{c|}{ Fall 2007 } & \multicolumn{2}{c|}{ Fall 2009 } \\
\hline $\begin{array}{c}\text { Sector of } \\
\text { institution and } \\
\text { employment } \\
\text { status }\end{array}$ & Number & Percent & Number & Percent & Number & Percent & Number & Percent \\
\hline Public 4-year & 369,635 & 100 & 387,230 & 100 & 419,519 & 100 & 437,858 & 100 \\
\hline Full time & 249,610 & 67.5 & 257,968 & 66.6 & 272,461 & 64.9 & 281,610 & 64.3 \\
\hline Part time & 120,025 & 32.5 & 129,262 & 33.4 & 147,058 & 35.1 & 156,248 & 35.7 \\
\hline & & & & & & & & \\
\hline $\begin{array}{l}\text { Private not-for- } \\
\text { profit 4-year }\end{array}$ & 286,610 & 100 & 299,989 & 100 & 318,905 & 100 & 337,742 & 100 \\
\hline Full time & 149,849 & 52.3 & 154,536 & 51.5 & 162,086 & 50.8 & 168,240 & 49.8 \\
\hline Part time & 136,761 & 47.7 & 145,453 & 48.5 & 156,819 & 49.2 & 169,502 & 50.2 \\
\hline & & & & & & & & \\
\hline
\end{tabular}




\begin{tabular}{|l|l|l|l|l|l|l|l|l|}
\hline & \multicolumn{2}{|c|}{ Fall 2003 } & \multicolumn{2}{c|}{ Fall 2005 } & \multicolumn{2}{c|}{ Fall 2007 } & \multicolumn{2}{c|}{ Fall 2009 } \\
\hline $\begin{array}{c}\text { Sector of } \\
\text { institution and } \\
\text { employment } \\
\text { status }\end{array}$ & Number & Percent & Number & Percent & Number & Percent & Number & Percent \\
\hline $\begin{array}{l}\text { Private for-profit } \\
\text { 4-year }\end{array}$ & 39,144 & 100 & 73,342 & 100 & 90,226 & 100 & 93,707 & 100 \\
\hline Full time & 6,874 & 17.6 & 10,439 & 14.2 & 10,856 & 12 & 13,724 & 14.6 \\
\hline Part time & 32,270 & 82.4 & 62,903 & 85.8 & 79,370 & 88 & 79,983 & 85.4 \\
\hline
\end{tabular}

Table 1. Number and percentage of instructional staff at Title IV degree-granting institutions other than medical schools, by sector of institution and employment status: United States, fall 2003, 2005,

2007, and 2009. Source: U.S. Department of Education, National Center for Education Statistics, Integrated Postsecondary Education Data System (IPEDS), Winter 2003-04, Employees by Assigned Position component, and Winter 2005-06, Winter 2007-08, and Winter 2009-10, Human Resources component, Employees by Assigned Position section.

Of course, the continued growth of employment in higher education is not surprising given the $22 \%$ growth of U.S. first-time enrollments from 2001 to 2010 . But, despite the rapid growth during this period of free university courseware, typically Open Course Ware, there is no indication of disruption of the basic business model of university education, as evidenced above in the levels of industry employment nor in any other possible indices, such as revenues, degrees granted, or enrollments.

The twin announcements by Coursera and EdX - the opening of a U.S. State Department and World Bank-supported MOOC platform (Coursera) and the pairing of Google with EdX to further develop the open-source platform is a demonstration of how far and how fast the MOOC phenomenon has taken hold.

The adoption by Antioch College of several MOOC courses from Coursera, the agreement with a U.S. accrediting body to review some Coursera courses for transferable credit, and the decision of the University of Washington and University of Texas systems to incorporate MOOCs to reduce tuition or costs all have antecedents in the ten-year history of Open Course Ware, particularly in the Asia region: both Korea and Indonesia had either institutional or systemic policies that supported credit-by-exam with Open Course Ware being used as the content to be studied. Other close parallels between the development of OCWs and MOOCs can be found in the "prestige" factor: the initial association of OCW with MIT and the later association of MOOCs with Stanford (Coursera, Udacity) and Harvard and MIT (Edx).

Educational systems perform a sorting function. Expectations of future earnings are created by a variety of selection processes. Some are based on ability to pay, but 
others are conditioned by past educational choices and achievements. Someone who has done poorly in mathematics would not be expected to end up as an economist or an engineer, for example. The point of the story of universal attainment of doctorates is that, immediately, a high degree of frustration would be felt by those who experience a mismatch between their skills and knowledge and their employment.

The case of Tunisia is telling in this regard. It was providing more support for higher education as a percentage of all education expenditures than the OECD average (Abdesalem, 2010). In fact, in terms of achieving public objectives, the results between 2000 and 2008 are excellent: (1) a doubling of science and technology graduates and an increase in their share of graduates from 29 to 34 percent; and (2) by $2007,59 \%$ of university students and $61 \%$ of graduates were female.

Furthermore, as elsewhere, earnings are correlated with educational attainment. However, unemployment rates show an inverse pattern: the higher the level of education, the more likely an individual is to be unemployed. Worse, the unemployment rate in the year after graduation had reached 61\% by 2006.

\begin{tabular}{|l|l|l|}
\hline & \multicolumn{1}{|c|}{ TND } & \multicolumn{1}{c|}{ Rate } \\
\hline Minimum Wage & 2,500 & 1 \\
\hline Public Administration remunerations & & \\
\hline Secondary ("Baccalauréat") & 4,200 & 1.7 \\
\hline University & & \\
\hline "Baccalauréat" +2 & 6,000 & 2.4 \\
\hline "Baccalauréat" +4 & 7,440 & 3.0 \\
\hline "Baccalauréat" +5 and above & 9,600 & 3.8 \\
\hline
\end{tabular}

Table 2. Some Indicators of Annual Wages by Education Level (20o8), Tunisia. Source: Ministry of Development and International Cooperation, Tunisia (Abdesalem, 2010) 


\begin{tabular}{|l|l|l|l|l|l|l|l|l|l|}
\hline Educational Level & 1994 & 2000 & 2001 & 2002 & 2003 & 2004 & 2005 & 2006 & 2007 \\
\hline None & 17.6 & 9.8 & 10.1 & 12.8 & 11.3 & 12.7 & 7.8 & 8 & 5.9 \\
\hline Primary & 18.3 & 17.3 & 17.1 & 16.6 & 15.8 & 15.7 & 15.7 & 15.2 & 13.5 \\
\hline Secondary & 13,1 & 18 & 16.4 & 15.9 & 15.3 & 14.7 & 14.9 & 14.3 & 15.4 \\
\hline Higher & 3.8 & 10.9 & 10.4 & 11.6 & 11.7 & 10.2 & 14.8 & 17.5 & 19 \\
\hline Overall & 15.6 & 15.7 & 15.1 & 15.3 & 14.5 & 14.2 & 14.2 & 14.3 & 14.1 \\
\hline
\end{tabular}

Table 3. Unemployment Rate by Educational Level in Tunisia (percent)Source: National Statistics Institute, General Census of Population and Housing and Population-Employment Surveys.

$$
\text { (Abdessalem, 2010) }
$$

\section{CONCLUSION}

The phase of universal access to higher education at a global level is neither short nor does it follow the same path across countries and regions. The role of web-based distance education was to serve as a cost reducer and an assurer of baseline quality in content. Open education now expands that opportunity even if for the foreseeable future distance and open education coexist, share technologies, and experience the same issues of audience: overcoming prior gaps in learning.

The barriers to raising the educational and cultural level of humanity are enormous and shouldn't be trivialized. Besides the financial barriers to higher education - for governments, institutions, and individuals - there is the urgent issue of harmonizing educational outcomes with social opportunity. In fact, the inversion of the typical pattern of higher employment and income for college graduates in Tunisia and Egypt were harbingers of the Arab Spring.

At the other end of the spectrum, sub-Saharan Africa, with its $7 \%$ tertiary gross enrollment ratios, stands to get larger benefits from the expansion of higher education. However, Africa will be the place that enters in a combined process both phases of mass education and universal access simultaneously, using distance and open education as twin levers for cost reduction and baseline quality.

Policy can only be intelligently made recognizing not only the scale offered by MOOCs, but the real educational and social challenges and opportunities to leverage higher education as a tool to eradicate poverty, address urgent global environmental problems, ensure public health and make "education for all" a reality. 


\section{REFERENCES}

Asplund, R.; Ben Adbelkarim, O.; Skalli, A. (2008). An Equity Perspective on Access to, Enrolment in and Finance of Tertiary Education. Education Economics, 16(3), (261-274).

Bloom, D.; Canning, D.; Chan, K. (2005). Higher Education and Economic Development in Africa.

Online Courseware. (s/f). Retrieved. [en línea] Disponible en: thefutureofhighered.blogspot.com/2012/12/whobenefits-from-free-online-courseware. html [consulta 2012, 29 de diciembre].

Human Development Sector Unit, World Bank. (2007). Strategic Directions for Higher Education in Turkey.

Military (2006). GI Bill turns 62 today. Military.com. [en línea] Disponible en: http://www.military.com/NewsContent/0,13319,102383,00.html [consulta 2013, 13 de octubre].

Peters, J. W.; Kopytof, Verne G. (2012). AOL to Buy The Huffington Post - NYTimes. com. [en línea] Disponible en: www. nytimes.com/2011/02/07/business/ media/o7aol.html [consulta 2012, 29 de diciembre].

Pompeo, J. (2012). Huffington Post live video strategy takes shape with new hires, a new name. Capital New York. [en línea] Disponible en: www.capitalnewyork. com/article/media/2012/05/5966448/ huffington-post-live-video-strategytakes-shape-new-hires-new-name [consulta 2012, 29 de diciembre].

Stiglitz, J. E. (2012) Student Debt and the Crushing of the American Dream." New York Times. [en línea] Disponible en: http://opinionator.blogs.nytimes. com $/ 2013 / 05 / 12 /$ student-debt-andthe-crushing-of-the-american-dream/ [consulta 2013, 30 de octubre].

Tahar Abdessalem, (2010). Financing Higher Education in Tunisia. Working Papers 551, Economic Research Forum.

Trow, M. (1973). Problems in the Transition from Elite to Mass Higher Education. Research. Berkeley, California: Carnegie Commission on Higher Education.

Unterhalter, M. (2006). Reflections on the Transition from Elite to Mass to Universal Access: Forms and Phases of Higher Education in Modern Societies since WWII. In: Altbach, P.; Forest, J. J. F. International Handbook of Higher Education. Ed. Philip G. Altbach and James J.F. Forest. 18. Dordrecht: Springer International. (243-280).

Vedder, R.; Denhart, C.; Robe, J. (2013). Why Are Recent College Graduates Underemployed? University Enrollments and Labor-Market Realities. Policy Paper. Washington, D.C.: Center for College Affordability and Productivity.

\section{ACADEMIC AND PROFESSIONAL PROFILE}

Larry Cooperman is the President of the OpenCourseWare Consortium, a global organization with more than 300 university and organizational members. He serves on the board of directors of the African Virtual University, a pan-African distance and open learning institution with partner universities in more than three dozen African countries. Cooperman is part of the management team at the University of California, Irvine, where he directs its OpenCourseWare project.

E-mail: Larry.Cooperman@unx.uci.edu 


\title{
ADDRESS:
}

\author{
130 Blaze, \\ Irvine, Ca 92618, USA
}

Fecha de recepción: 15/07/2013

Fecha de aceptación: 09/11/2013

\section{Como citar este artículo:}

Cooperman, L. (1014). De la educación superior de elite a la masiva universal: de educación a distancia a la abierta. RIED. Revista Iberoamericana de Educación a Distancia, volumen $17, \mathrm{n}^{\mathrm{O}} 1$, pp. 111-130. 